\title{
The Signs of Pancreatic Degenerative Atrophy in Dogs and the Role of External Factors in the Ethiology of the Disease
}

\author{
By Maija Ràiha and Elias Westermarck \\ MEVET Small Animal Clinic and \\ Department of Clinical Sciences, College of Veterinary Medicine, Helsinki, Finland.
}

\begin{abstract}
Räiha, $M$. and $E$. Westermarck: The signs of pancreatic degenerative atrophy in dogs and the role of external factors in the ethiology of the disease. Acta vet. scand. 1989, 30, 447-452. - A questionnaire was sent to 109 owners of German Shepherds suffering from pancreatic degenerative atrophy (PDA) and to 186 owners of German Shepherds with no known history of PDA. Owners were asked questions about their dogs adolescense, e.g. rate of growth, diseases and training. Detailed questions about feeding, intestinal and skin problems were also asked. In the questionnaire for PDA - dogs questions were divided into two parts: before and after the onset of PDA signs.

Based on this study no specific early signs of PDA or causative factors could be found. The role of stress as a triggering factor could not, however, be totally excluded. The frequency of typical signs of PDA was outlined and also some signs not previously reported as typical PDA-signs were noted.
\end{abstract}

exocrine pancreas; German Shepherd; digestion.

\section{Introduction}

Pancreatic degenerative atrophy (PDA) is a disease that occures especially in German Shepherds (Freudiger 1976). It has been stated that PDA is inherited as an autosomal resessive trait in this breed (Westermarck 1980). In many inherited diseases there occurs an interaction between host-associated and enviromental factors. The former include breed, sex and age. The latter include diet, housing, husbandry and exposure to toxic and infectious agents (Thrusfield 1988). The role of the enviromental factors in the ethiology of PDA has not been studied before. Resent studies show that PDA is an atrophic disease (Pfister et al. 1980). Factors that are involved in causing or triggering this atrophying process and the rate of which it proceeds remain yet unknown. Clinical signs of PDA appear generally when the dogs are young adults (Säteri 1975). The occurrence of possible signs of PDA during the adolesence has not been studied before.

Clinical signs of PDA such as increased appetite, weight loss and loose stools are well known (Hill 1978) but there are no previous reports on the frequency of these signs.

The objectives of this study are:

- to show if dogs that developed PDA had signs suggestive of PDA already during their adolesence;

- to show if any external circumstances during adolesence or just before the onset of PDA-signs are involved in directly causing or triggering PDA;

- to list the frequency of the most common signs of PDA and also to look for signs not previously noted as typical PDAsigns.

\section{Materials and methods}

A questionnaire was sent to 109 owners of 
German Shepherds with PDA (returned by $76=70 \%$ ) and to 186 randomly selected owners of German Shepherds with no known history of PDA (returned by $134=72 \%$ ). The diagnosis of PDA was based on clinical signs combined with a soybean stimulation test (Westermarck \& Sandholm 1980). Eleven PDA-dogs were alive during the study. Necropsy had been performed on 45 of the dogs that had subcommed or had been euthanized and the diagnosis of PDA was confirmed in every case.
The PDA-group consisted of 38 males and 38 females and the control group of 70 males and 63 females. The average age of the dogs in the control group was $4.1 \pm 2.1$ years (SEM).

In both questionnaires owners were asked questions about their dogs living conditions during adolesence e.g. rate of growth, feeding regimes and training. Also detailed questions about diseases, especially intestinal and skin problems, were asked.

The questionnaire for owners of PDA-dogs

Table 1. Data from adolescence prior to the onset of PDA-signs.

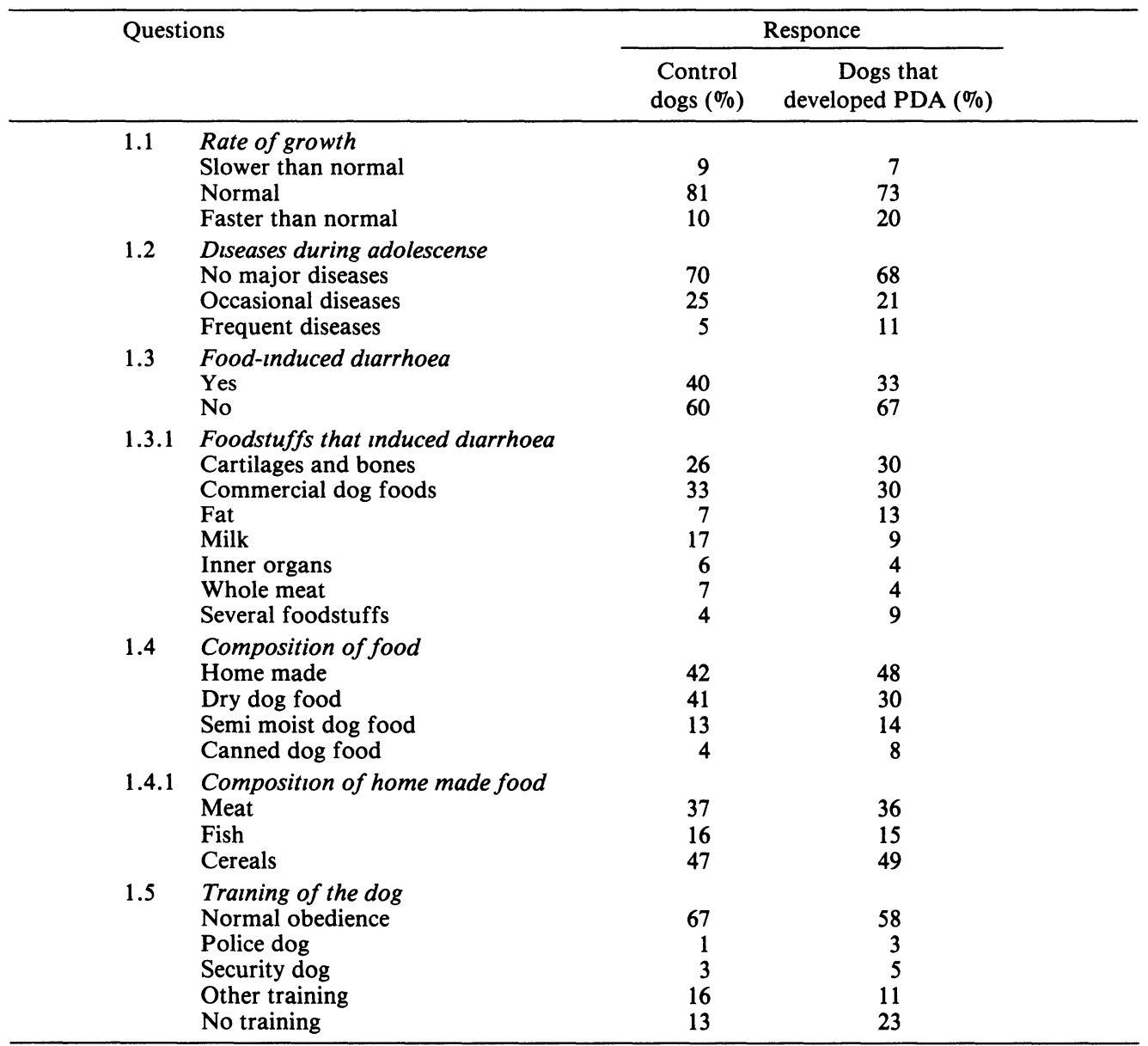


was divided into two parts: conditions before and after the onset of PDA-signs.

Statistical analysis of the material was performed by using a chi square test.

\section{Results and discussion}

It is quite widely accepted that PDA is an atrophying disease (Säteri 1975), but it is not known at what age the atrophying process starts in the pancreas. It has also been reported that PDA is a hypoplastic disease ( $\mathrm{Hol}$ royd 1968). If this is the case or if the atrophying process starts at a very early age, affected dogs should exhibit signs of pancreatic dysfunction during their adolesence. In this study we found that the growth rate of most dogs, both in the PDA-group and the control group, was normal (Table 1.1). In both groups a third of the dogs suffered from diarrhoea induced by various foods (Table 1.3). Dogs that later in life developed PDA suffered from fat-induced diarrhoea more often than control dogs. This could be considered as a first sign of PDA, but the difference between the two groups was not statistically significant (Table 1.3.1).

Data in Table 3 shows that appetite, body condition, body weight, water consumption, frequency of vomiting, flatulence, tenderness of the abdomen and matters connected with defecation (consistency, colour, amount of feces) did not differ significantly between the PDA-dogs, prior to onset of PDA-signs, and the control group. However, dogs that later in life developed PDA, defecated significantly more often before the onset af PDA-signs than control dogs. In both groups dogs exhibited coprophagia of their own or other dogs feces. As a general remark it can be noted that more than one tenth of the control dogs exhibited coprophagia in some form. According to this study, no early signs suggestive of PDA could be seen in dogs that later developed PDA.

External conditions and events in the life of the dogs that later developed PDA were very similar to those of the control dogs (Table 1). The different training patterns showed

Table 2. Data from the time of onset of PDA-signs.

\begin{tabular}{|c|c|c|}
\hline \multicolumn{2}{|c|}{ Questions } & \multirow[b]{2}{*}{$\begin{array}{c}\text { Responce \% } \\
\\
12 \\
28 \\
53 \\
7\end{array}$} \\
\hline 2.1 & $\begin{array}{l}\text { Age of the dog at the onset of signs } \\
\text { (years) } \\
<1 \\
1-2 \\
2-4 \\
>4\end{array}$ & \\
\hline 2.2 & $\begin{array}{l}\text { Changes in the dogs life immediately } \\
\text { prior to the onset of slgns } \\
\text { New owner } \\
\text { Boarding away from home } \\
\text { Increased training } \\
\text { New family member } \\
\text { Change in the diet } \\
\text { Other reasons } \\
\text { No changes }\end{array}$ & $\begin{array}{r}5 \\
1 \\
5 \\
3 \\
3 \\
20 \\
63\end{array}$ \\
\hline 2.3 & $\begin{array}{l}\text { Other diseases ımmediately prior to the } \\
\text { onset of signs } \\
\text { Severe diarrhoea } \\
\text { Severe vomiting } \\
\text { Tenderness of the abdomen } \\
\text { Other diseases } \\
\text { No diseases }\end{array}$ & $\begin{array}{r}25 \\
3 \\
0 \\
8 \\
64\end{array}$ \\
\hline
\end{tabular}


no significant differences between the two groups. Most dogs were ordinary household pets (Table 1.5). Differences in the composition of food were very small (Table 1.4). These results indicate that PDA most likely is not a result from erroneous feeding or a deficiency disease. This study is however, not sufficient to detect a deficiency of some micronutrient as a causative factor of PDA. After all it is known that pancreatic atrophy in chickens can be experimentally induced by selenium deficiency (Thompson \& Scott 1970). These results suggest that external factors are very unlikely to be causative factors in the ethiology of PDA.

In this study most dogs (93\%) exhibited signs of PDA before the age of 4 years (Table 2.1). Special attention was given to the time immediately prior to the onset of PDAsigns. It is known that the onset of some diseases (e.g. autoimmune diseases) are preceded by a stress factor or some other disease (Garman \& Werner 1986). Our results show that almost one third of the dogs that developed PDA had noticeable changes in their living conditions immediately prior to

Table 3. Summary of major signs in PDA-dogs compared with control dogs.

\begin{tabular}{|c|c|c|c|}
\hline & Control dogs $(\%)$ & $\begin{array}{l}\text { PDA-dogs prior to the } \\
\text { onset of signs }(\%)\end{array}$ & $\begin{array}{l}\text { PDA-dogs after the onset } \\
\text { of signs }(\%)\end{array}$ \\
\hline Good appetite & 53 & 53 & 40 \\
\hline Abnormally increased appetite & 3 & 7 & $53^{\mathrm{xxx}}$ \\
\hline Lean body or cachexia & 26 & 33 & $90^{\mathrm{xxx}}$ \\
\hline $\begin{array}{l}\text { Defecation more than } \\
3 \text { times/day }\end{array}$ & $\times 4$ & 14 & $90^{\mathrm{xxx}}$ \\
\hline Large amounts of feces & 15 & 22 & $95^{\mathrm{xxx}}$ \\
\hline Poorly digested feces & 1 & 1 & $61^{\mathrm{xxx}}$ \\
\hline Grey or yellowish feces & 13 & 18 & $99^{x \times x}$ \\
\hline Diarrhoea several tımes/week & 1 & 3 & $77 \times x x$ \\
\hline Frequent defecation indoors & 1 & 4 & $56^{\mathrm{xxx}}$ \\
\hline $\begin{array}{l}\text { Occasional coprophagia of other } \\
\text { dogs feces }\end{array}$ & 14 & 12 & $29^{x}$ \\
\hline $\begin{array}{l}\text { Occasional coprophagia of own } \\
\text { feces }\end{array}$ & 12 & 22 & $61^{x \times x}$ \\
\hline Frequent flatulence & 22 & 25 & $88^{x \times x}$ \\
\hline $\begin{array}{l}\text { Occasional tenderness of } \\
\text { the abdomen }\end{array}$ & 3 & 1 & $28^{\mathrm{xxx}}$ \\
\hline Polydipsia & 3 & 8 & $51^{x \times x}$ \\
\hline Frequent vomiting & 14 & 5 & $38^{\mathrm{xxx}}$ \\
\hline Monthly skin problems & 10 & 8 & 14 \\
\hline $\begin{array}{l}\text { Temperament } \\
\text { - nervous or aggressive } \\
\text { - apathetic }\end{array}$ & $\begin{array}{l}6 \\
0\end{array}$ & $\begin{array}{l}7 \\
0\end{array}$ & $\begin{array}{l}31^{x x x} \\
11^{x x x}\end{array}$ \\
\hline
\end{tabular}

Stars on the left side of the columns represent statistical differences between control dogs and PDA-dogs prior to the onset of signs.

Stars on the right side of the columns represent statistical differences between control dogs and PDA-dogs after the onset of signs.

$\mathrm{x}: \mathrm{p}<0.05$

${ }^{x x}: p<0.01$

${ }^{\mathrm{xxx}}: \mathrm{p}<0.001$ 
the onset of PDA-signs (Table 2.2). Also almost one third suffered from some other disease. A fourth of the dogs had suffered from severe diarrhoea before signs of PDA occurred (Table 2.3). It is difficult to estimate whether diarrhoea provoked PDA or whether severe diarrhoea already was a sign of PDA. Allthough no specific triggering factors could be found, the role of stress in one form or another can not be excluded.

After the onset of PDA-signs PDA-dogs differed significantly from control dogs (Table 3). Their appetite increased. More than half of the PDA-dogs constantly wanted food. There was a clear increase in water consumption, which has not been reported before to be a typical sign for PDA. The frequency of defecation and the amount of feces also increased significantly among the PDA-dogs. In two thirds of the PDA cases feces became poorly digested and in all cases the colour of the dogs feces turned grey or yellowish. After the onset of signs there was an increse in diarrhoea, defecating indoors, flatulence and coprophagia, especially of their own poorly digested feces. Vomiting also increased markedly, a sign that has not been considered typical of PDA. After the onset of signs tenderness of the abdomen increased somewhat. This propably is due to increased amounts of gas in the intestines. The nature of some dogs changed after the onset of signs; some became apathetic and some became nervous and aggressive. The general discomfort caused by severe intestinal problems could be the reason for behavioral changes in PDA-dogs.

In previous reports it has been stated that dry skin and skin problems generally are typical for PDA-dogs (Freudiger 1979, Johnson 1980). In this study detailed questions about skin problems were asked in the questionnaires. Information about frequency, type of skin problem e.g. pruritus, sca- ling, abnormal hair loss and condition of the skin it self e.g. dry or oily skin was sought (data not shown). Suprisingly, PDA-dogs did not have skin problems more often than control dogs and the nature of the problems were much the same in both groups.

The results of this study outline the signs of PDA more precicely than in earlier studies, but a reliable diagnosis of PDA is confirmed only by combining various laboratory tests with clinical signs and a detailed history.

\section{References}

Freudiger $U$ : Epidemiologie, Átiologıe, Klinik und Diagnose der chronischen exokrinen Pankreasinsuffizienz. (Epidemiology, ethiology, clinical picture and diagnosis of chronic exocrien pancreatic insufficiency) Prakt. Tierarzt. 1976, 57, 300-314.

Freudiger $U$ : Die Diagnose der chronischen exokrinen Pankreasinsuffizienz. (The diagnosis of chronic exocrine pancreatic insufficiency) Kleintier - Praxis. 1979, 24, 375-387.

Garman NT, Werner LL: Diagnosis of immunomediated diseases interpretation of immunologic tests. Current Veterinary Therapy IX Small animal practice. W. B. Saunders company, Philadelphia 1986, p. 427-435.

Hill FWG: Pancreatic disorders of dogs. Vet. Annu. 1978, p. 198-211.

Holroyd JB: Canine exocrine pancreatic disease. J. Small Anim. Pract. 1968, 9, 269-281.

Johnson GF: Exocrine pancreatic insufficiency. In: Veterinary Gastroenterology. Ed. Anderson NV: Lea \& Febiger, London 1980, p. 637-643.

Pfister K, Rossl GL, Freudiger U, Bigler B: Morphological studies in dogs with chronic pancreatic insufficiency. Virchows Archiv A 1980, 386, 91105.

Sater $H$ : Investigation on the exocrine pancreatic function in dogs suffering from chronic exocrine pancreatic insufficiency. Acta vet. scand. 1975, Suppl. 53, pp 1-86.

Thompson JN, Scott ML: Impaired lipid and vitamin $\mathrm{E}$ absorption related to atrophy of the pancreas in selenium deficient chicks. J. Nutr. 1970, 100, 797-809. 
Thrusfield M: Is it hereditary?: 1 . The cause of disease. J. small Anim. Pract. 1988, 29, 603-609.

Westermarck $E$ : The hereditary nature of canine pancreatic degenerative atrophy in the German Shepherd dog. Acta vet. scand. 1980, 21, 389. 394.

Westermarck $E$, Sandholm M: Faecal hydrolase activity as determined by radial enzyme diffusion - a new method for detecting pancreatic dysfunction in the dog. Res. Vet. Sci. 1980, 28, 341-346.

\section{Sammanfattning}

Symptom vid degenerative atrofi l bukspottskorteln hos hund och yttre factorers roll $i$ sjukdomens etiologl.

Ett frågeformular skickades till 109 agare av schaferhundar med atrofi i bukspottkorteln (PDA) och till 186 agare av kliniskt friska schafer-hundar. Frågorna gallde bl.a. hundens uppvaxtperiod, tillvaxthastighet, sjukdomar och skolning. Detaljerade frågor stalldes angående utfodring, tarmproblem samt hudproblem. Två grupper av frågor ingick i frågeformularen for PDA-hundar: fore och efter symptomens bơrjan. På basen av denna undersokning kunde inga specifika symptom på begynnande PDA eller faktorer som skulle orsaka sjukdomen påvisas. Stressens roll som utlosande faktor kunde dock inte helt uteslutas. Vi redogjorde for frekvensen av typiska symptom for PDA och noterade en del symptom som annu inte rapporteratrs som kannspaka for PDA.

(Recieved January 10, 1989; accepted February 20, 1989).

Reprints may be requested from: Maija Raiha, MEVET Small Animal Clinic, Ulvilantic 25, SF-00350 Helsinki, Finland. 